University of Warwick institutional repository: http://go.warwick.ac.uk/wrap This paper is made available online in accordance with publisher policies. Please scroll down to view the document itself. Please refer to the repository record for this item and our policy information available from the repository home page for further information.

To see the final version of this paper please visit the publisher's website. Access to the published version may require a subscription.

Author(s): Kümin, Beat

Article Title: Useful To Have, But Difficult To Govern. Inns and Taverns in Early Modern Bern and Vaud

Year of publication: 1999

Link to published version: http://dx.doi.org/ 10.1163/157006599X00035

Publisher statement: None 


\title{
Useful to have, but difficult to govern. \\ Inns and taverns in early modern Bern and Vaud
}

\author{
BEAT KÜMIN \\ University of Bern
}

\begin{abstract}
This essay examines the significance of inns and taverns in the early modern period. Drawing above all on a series of registers from the French and German lands of the Swiss Republic of Bern, the discussion is presented in two parts. A first section investigates structural aspects such as ownership, clientele and the remarkably multifunctional character of these establishments. Part II illustrates the continuing growth in provision during the Ancien Régime and the limited impact of government regulation. It is argued that inns and taverns became the most prominent social centres in early modern local communities and that popular demand for their services prevailed over sustained campaigns to restrict numbers and discipline patrons.
\end{abstract}

Travelling through European towns and villages, visitors are struck not only by castles, churches or town halls, but also a good number of ancient inns. Many landlords or brochures proudly emphasize the age-old tradition of their houses, some of which preserve impressive late medieval or early modern features. ${ }^{1}$ For those interested in distant history as well as current appearance, however, information is not very easy to obtain. Given the deluge of primary sources, from architectural evidence through to detailed inventories, it is puzzling to find at best one or two marginal references to the subject in the standard social and economic textbooks. Bibliographical research leads to thousands of specialised studies on particular regions, individual establishments or current scholarly debates such as gender, the history of crime or sociability, ${ }^{2}$ but there are as yet few general surveys of

\footnotetext{
${ }^{1}$ See for instance the Riesen in Miltenberg, commonly mentioned as one of the oldest German inns (e.g. Brockhaus Enzyklopädie (17th edn., Wiesbaden 1971), xii. 570-571), or the impressive sixteenth-century structure of the Bear at Münsingen near Bern. For landlord dynasties: Fréderic Ammann, “Traditionsreiche Berner Wirte,” Berner Zeitschrift für Geschichte und Heimatkunde 39 (1977), 1-5, or Josef Weingartner, Berühmte Tiroler Wirtshäuser und Wirtefamilien (Innsbruck, 1956).

${ }^{2}$ Beatrix Beneder, Männerort Gasthaus? Öffentlichkeit als sexualisierter Raum (Frankfurt, 1997); Michaela Hohkamp, “Vom Wirtshaus zum Amtshaus,” Werkstatt Geschichte 16 (1997), 8-18; Katja Hürlimann, “Öffentlicher Konsum in Wirtshäusern. Soziale Funktion
} 
more than anecdotal character. ${ }^{3}$ Following a number of important fresh approaches within the last decade, most notably studies on the late medieval origins of commercial hospitality, the cultural dimensions of the trade in urban environments and the long-term development of English alehouses, ${ }^{4}$ this essay attempts to provide an assessment of the social importance of inns and taverns in early modern Central Europe. ${ }^{5}$

Much of the empirical evidence advanced for this purpose derives from the early modern Swiss republic of Bern, "the largest city state north of the Alps," ${ }^{6}$ which included as a result of conquests in 1415 and 1536 - parts of the present-day canton of Aargau as well as the French-speaking Pays de Vaud. These German and French lands extended over a very substantial area from the outskirts of Geneva all the way to the borders of Zurich, with a population of perhaps 150,000 inhabitants in the mid-sixteenth century and some

des Konsums in den Zürcher Landvogteien Greifensee und Kyburg im 15./16.

Jahrhundert,” Geschichte der Konsumgesellschaft, ed. Jakob Tanner et al. (Zurich, 1998), 147-163; Simon Teuscher, Bekannte - Klienten - Verwandte. Soziabilität in der Stadt Bern um 1500 (Weimar, 1998).

${ }^{3}$ Impressionistic general accounts include Theodor von Liebenau, Das Gasthof- und Wirtshauswesen der Schweiz in älterer Zeit (Zurich, 1891); Ossip Demetrius Potthoff and Georg Kossenhaschen, Kulturgeschichte der deutschen Gaststätte, umfassend Deutschland, Österreich, die Schweiz und Deutschböhmen (Berlin, 1933 [reprint: Hildesheim, 1996]); Friedrich Rauers, Kulturgeschichte der Gaststätte (2 vols., Berlin, 1941); Ulla Heise, Der Gastwirt. Geschäftsmann und Seelentröster (Leipzig, 1993).

${ }^{4}$ Hans Conrad Peyer, Von der Gastfreundschaft zum Gasthaus. Studien zur Gastlichkeit im Mittelalter (Hannover, 1987); Thomas Brennan, Public Drinking and Popular Culture in Eighteenth-Century Paris (Princeton, 1988); B. Ann Tlusty, “The Devil’s Altar. The Tavern and Society in Early Modern Augsburg” (Ph.D. University of Maryland, 1994); Peter Clark, The English Alehouse. A Social History 1200-1830 (London, 1983); Judith M. Bennett, Ale, Beer and Brewsters in England. Women's Work in a Changing World 13001600 (Oxford, 1996).

${ }^{5}$ The following is an intermediate summary of a larger research project on early modern inns and taverns supported by the Swiss National Science Foundation.

${ }^{6}$ Christian Pfister and Hans Rudolf Egli, Historisch-Statistischer Atlas des Kantons Bern 1750-1995. Umwelt, Bevölkerung, Wirtschaft, Politik (Bern, 1998), 34. 
400,000 by the end of the Ancien Régime. ${ }^{7}$ Bern was a relatively prosperous state governed by a patrician city council, which adopted the reformed religion in 1528 and played a leading diplomatic and military role in the Swiss confederation. The subject areas of Aargau and Vaud, which remained Bernese until the Helvetic revolution of 1798, were administered by a very small number of central officials much like the core territory, with considerable respect for ancient custom and linguistic tradition. ${ }^{8}$ Among the many potential sources of information on inns and taverns, the most convenient is a set of detailed registers compiled on the basis of reports from local officials during the seventeenth and eighteenth centuries. ${ }^{9}$ In addition, there is a substantial amount of work from local historians, ranging from a close examination of a fifteenth-century landlord's account books to a monograph on the Falcon, the city of Bern's foremost inn, and a series of studies on the economic importance of the catering trade at the end of the Ancien Régime. $^{10}$

\footnotetext{
${ }^{7}$ Markus Mattmüller, Bevölkerungsgeschichte der Schweiz. Die frühe Neuzeit 1500-1700 (2 vols, Basle, 1987), i. 121-4; Pfister and Egli, Historisch-Statistischer Atlas, 34.

${ }^{8}$ The standard work on the political history remains Richard Feller, Geschichte Berns (4 vols., Bern, 1946-60), but see also Berner - Deine Geschichte, ed. Peter Meyer (Bern, 1988), and for socio-economic aspects Christian Pfister, Im Strom der Modernisierung.
} Bevölkerung, Wirtschaft und Umwelt im Kanton Bern 1700-1914 (Bern, 1995). For the Vaud cf. Auguste Verdeil, Le Pays de Vaud sous la domination de Berne (XVIe-XVIIIe siècles) (Reprint Paris, 1992), L'histoire vaudoise, ed. Henri Meylan (Lausanne, 1973), and De l'Ours à la Cocarde. Régime bernois et révolution en Pays de Vaud 1536-1798, ed. François Flouck et al. (Lausanne, 1998).

${ }^{9}$ Staatsarchiv Bern [herafter StA BE], B V 142 (1628), B V 143 (1688), B V 144 (1743) and B V 148 (1785-86).

${ }^{10}$ Vinzenz Bartlome, Die Rechnungsbücher des Wirtes Hans von Herblingen als Quelle zur Wirtschaftsgeschichte Thuns um 1400 (Bern, 1988); Margrit Rageth-Fritz, Der Goldene Falken. Der berühmteste Gasthof im alten Bern. Das Zunfthaus zum Mittellöwen (Bern, 1987); studies by Anne Radeff on the eighteenth-century economy include: "Le réseau des auberges vaudoises au XVIIIe siècle,” Revue Historique Vaudoise 101 (1993), 125-137, Du café dans le chaudron. Economie globale d'Ancien Régime. Suisse occidentale, Franche-Comté et Savoie (Lausanne, 1996), and “Des villes sujettes,” De l'Ours à la Cocarde, 281-309. 
The argument is divided in two parts. A first section highlights the role of hostelries by looking at structural aspects like numbers, locations, patrons and owners as well as the wide range of functions documented in the sources. Part II examines the remarkable resilience and vitality of these institutions in the face of pressure from external authorities. To avoid misunderstandings, "inn” will be used for an establishment with overnight accommodation and "tavern” for places where only wine was sold. In early modern Swiss German, however, Taverne designated an inn, whilst Pintenschenke corresponded to the English term tavern.

Absolute numbers provide a first impression of the importance of the phenomenon. Early modern statistics are notoriously unreliable, but according to an official survey for the state of Bern in 1628 we find - taking all different types of institutions together - a total of 494 establishments (on average 1 per 425 inhabitants, varying between 1:369 in the German lands and 1:532 in the Pays de Vaud), which compares to a much denser provision of 1 per 175 inhabitants in a similar register compiled for the whole of England in 1577. The marked difference can be attributed to a deluge of over 15,000 alehouses in the English countryside, a type of establishment which simply did not exist in the vine-growing regions of Bern at the time. Looking exclusively at the availability of overnight accommodation, we find 1 inn per 640 souls in the Swiss case study, compared to a modest 1 per 1100 in England. ${ }^{11}$ All of these calculations, it goes without saying, are based on absolute minimum figures of known institutions. What is conspicuously missing, for instance, is an estimate of the informal sale of the vintners' and vine-growers' own produce, which must have been extensive. The city of Bern is thought to have had 200 publicly accessible wine

\footnotetext{
${ }^{11}$ The figures have been compiled from StA BE, B V 142, passim (328 inns, 58 taverns and 4 hostelries in thermal spas were considered to be properly established and necessary, while 104 institutions appeared to have no formal proof of their rights of existence); the ratios are based on a population estimate of 210,000 inhabitants in the early seventeenth century (cf. note 7 above). For England see the - somewhat varying - calculations in Clark, Alehouse, 43, and John A. Chartres, “The English inn and road transport before 1700,” Gastfreundschaft, Taverne und Gasthaus im Mittelalter, ed. Hans Conrad Peyer (Munich, 1983), 153-176, esp. 166-167, both based on Public Record Office, State Papers Domestic, SP/12/96, 12/116-19, 12/122.
} 
cellars stocked with the burghers' own wine, ${ }^{12}$ and most of the smaller towns exercised similar rights. A chance eighteenth-century reference to the situation at Payerne, for example, reveals the existence of 10 such informal drink outlets on top of the official 4 inns and 2 taverns. ${ }^{13}$

Commercial hospitality could be found in countless different locations, but normally near places where large groups of people met: on market or village squares, near city gates, churches and town halls, on major streets, waterways or river crossings. In 1571, for example, the Bernese council acknowledged a legitimate public demand in "towns and larger villages, on mountain passes and highways, as well as at all places where court assemblies are held." ${ }^{14}$ A basic network of hostelries was indispensable for economic as well as practical reasons. An explicit motive for the compilation of the register of 1688 was the hope, "that this necessary revision [of provision] would allow travellers to find convenient accommodation on their journeys," while regulations of prices and services were needed to prevent "foreign tradesmen from using other roads and taking their goods elsewhere.”15

It is difficult to generalize on who attended all these establishments. Most importantly for sites of social exchange, they operated under the principle of general accessibility. Nearly all relevant statutes charged landlords with the duty to admit all members of the public, apart from a narrow range of criminal or dangerous individuals. ${ }^{16}$

12 Adolf Lechner, “Etwas von den bernischen Kellerwirtschaften,” Neues Berner Taschenbuch (1910), 278-301.

${ }^{13}$ StA BE, B V 144, 86.

${ }^{14}$ Sammlung Schweizerischer Rechtsquellen. Abt. II: Die Rechtsquellen des Kantons Bern. 1. Teil: Stadtrechte, vol. VIII/1: Wirtschaftsrecht, ed. Hermann Rennefahrt (Aarau, 1966), 199-200 (“allein die rechten ordenlichen tavernen in den stetten und grossen dörfferen, an den pässen und hochstrassen und an denen orten, da man gewont hat, gricht zehalten, belyben zelassen”). For a survey of common locations cf. Gertrud Benker, Der Gasthof. Von der Karawanserei zum Motel. Vom Gastfreund zum Hotelgast (Munich, 1974), 69-76. ${ }^{15}$ StA BE 143, 36 (1688; the government hoped "daß an denen Land vnd anderen Straßen in Stetten vnd Dörferen, die Reisenden die nöhtige Comligkeit wegen den Herbergen finden”); Stadtrechte, vol. VIII/1, ed. Rennefahrt, 208 (1619; to prevent “frömbde handels und andere persohnen” from “andere strassen zebruchen und ire gu(e)ter und wahren neben ab vertigen zelassen”).

${ }^{16}$ Heise, Gastwirt, 68-70; see e.g. the lease of the Lion at Idstein in the German county of Nassau-Idstein in 1692 (cited in Potthoff and Kossenhaschen, Kulturgeschichte der 
Then as now, however, people could choose from a great range of institutions. VIP-hotels for the nobility or official state visitors, such as the Falcon in Bern, contrasted with noisy cellar rooms in the darkest backstreets of a town. ${ }^{17}$ Smaller-scale alehouses and taverns, in particular, have often been described as places of refuge for the poor. ${ }^{18}$ The task of recreating a more specific customer profile for a particular institution is difficult. Occasionally there are guest books with signatures of individual patrons, court records concerning offenders arrested in a tavern, account rolls with names of debtors or menu lists with notes on the parties catered for. ${ }^{19}$ In smaller rural places, in any case, hostelries must have accommodated a colourful range of nationalities and people from different social backgrounds, professions and age groups. Contemporary evidence, such as Erasmus’ famous description of an early sixteenth-century German inn, where all sorts of people ate the same meal at the same table, illustrates the ubiquity of such encounters. ${ }^{20}$ Present-day social historians, too, regard inn and taverns as "particularly well suited to forge socially diverse groupings," even in towns. ${ }^{21}$

deutschen Gaststätte, 486-487), the oath of Neuchâtel innkeepers in 1694 (to accept "tous estrangers passans et autres allans venans et séjournans tant à pied qu'à cheval”: Arthur Piaget, “Octrois de 'schild',” Musée neuchâtelois (1901), esp. 97-98) or the common law principle known as the “innkeepers' rule”.

${ }^{17}$ A network of first-class accommodation around 1500 appears in the diary of two Venetian envoys travelling to southern Germany: "Ein venetianischer Reisebericht über Süddeutschland, die Ostschweiz und Oberitalien aus dem Jahre 1492,” ed. Henry Simonsfeld, Zeitschrift für Kulturgeschichte 2 (1894), 241-283.

${ }^{18}$ Clark, Alehouses, 123 (England around 1600); Jacques Soubeyroux, Pauperisme et rapports sociaux à Madrid au XVIIIème siècle (2 vols., Lille, 1978), esp. i. 198 (late eighteenth-century Madrid).

${ }^{19}$ Examples include Luise Vöchting-Oeri, “Der Gasthof zum Wilden Mann in Basel als Herberge vornehmer Reisender zu Beginn des 30-jährigen Krieges,” Basler Zeitschrift für Geschichte und Altertumskunde (1944), 91-118 (guest book with coats of arms and signatures of noble visitors); Hohkamp, "Wirtshaus” (participants in tavern brawls); Barbara Roth-Lochner, “Les repas du graveur Fournier à l'auberge de Grange-Canal (177883),” Revue du Vieux-Genève (1991), 42-51 (list of debtors); Rageth-Fritz, Falken, 212216 (list of menus and parties).

${ }^{20}$ Desiderius Erasmus, Colloquia familiaria (many edns from 1523), “Diversoria”.

${ }^{21}$ Teuscher, Soziabilität, 197 (quote); Tlusty, “The Devil’s Altar,” 20. 
Looking at visitors from the point of view of gender, there seems to be a general feeling that women stopped going to the pub in the early modern period..$^{22}$ One recent study advanced a most imaginative theory, claiming that hostelries underwent a gradual process of "masculinization" accompanied by the "erotic functionalization" of women, culminating in a bourgeois society where a strictly men-only clientele indulged in the pleasures of social eating and drinking, whilst an exclusively female staff did all the dirty work. Unfortunately, the thesis suffers from a distinct lack of empirical evidence for the early modern period. The argument is based mainly on anecdotes drawn from secondary material and an uncritical reading of literary texts. ${ }^{23}$ The Bernese sources, in contrast, suggest a rather more complex picture. Women could be conspicuously absent, as in negotiations about marriage contracts which Emmental fathers tended to conduct over a good bottle in the local inn, ${ }^{24}$ but in other circumstances they attended well into the seventeenth and eighteenth centuries. Prospective mothers, for instance, benefited from special privileges, with many establishments explicitly charged to provide them with enough wine of good quality during childbirth. ${ }^{25}$ As for other female visitors, it seems reasonable to assume contextual and regional variations. Whilst we are unlikely to find ladies from the highest social groups alone in isolated taverns, women were clearly happy to take part in the local festive culture, for without them there would have hardly been so many dances at so many hostelries. ${ }^{26}$ In certain areas, female tavern guests tended to be wives accompanying their husbands, elsewhere the local pub offered maidens the main

${ }^{22}$ Robert Muchembled, Société et mentalités dans la France moderne XVIe - XVIIIe siècle (Paris, 1990), 169; similar Richard van Dülmen, Entstehung des frühneuzeitlichen Europa 1550-1648 (Frankfurt, 1982), 208.

${ }^{23}$ Beneder, Männerort Gasthaus?

${ }^{24}$ Alice Leibundgut-Mosimann, “Emmentaler Eheverträge,” Berner Zeitschrift für Geschichte und Heimatkunde 42 (1980), 33-80, esp. 35.

${ }^{25}$ Wine was considered a powerful medicine. For an example see StA BE, B V 143, 8 (tavern in Buchholterberg near Thun).

${ }^{26}$ Substantial evidence for dancing in a number of early modern Bernese parishes in Heinrich R. Schmidt, Dorf und Religion. Reformierte Sittenzucht in Berner Landgemeinden der frühen Neuzeit (Stuttgart, 1995), esp. 133-134 (inns and taverns as venues). 
opportunity to mix socially and to look for potential spouses. ${ }^{27}$ Commenting on regional patterns, historians have observed that women failed to attend inns and taverns in the Neuchâtel region of the Jura, as opposed to the German-speaking areas of Bern where they were certainly present. ${ }^{28}$ At rural Wyden in 1650, for instance, the local consistory court fined "Hans Flümann for drinking after hours with his wife" and for failing to "make any serious attempt to stop her from frequenting the tavern," while Elizabeth Herren was ordered to pay 10 shillings for "dancing at the inn" in $1681 .^{29}$ Neither should we forget the prominent role of landladies. From numerous references in manorial records and a recent monograph on English alewives, we know a lot about the importance of female hosts - at least until the rise of larger-scale industrialized brewing, while women were equally conspicuous among the owners of smaller-scale taverns in the Vaud..$^{30}$ In an as yet fragmentary database of early modern Bernese landlords and -ladies, women account for 62 out of some 1200 individuals (or just over 5\%), which is a considerable proportion given the fact that they are much less likely to appear in official sources. ${ }^{31}$

${ }^{27}$ Tlusty, “The Devil's Altar,” 440 (wives of Augsburg craftsmen); Albert Tanner, Spulen Weben - Sticken. Die Industrialisierung in Appenzell Ausserrhoden (Zurich, 1982), 303 (taverns as meeting-points for young people in eighteenth-century Appenzell).

${ }^{28}$ Radeff, Café dans le chaudron, 219-220. The presence of women in taverns is also documented in, say, late eighteenth-century Madrid: Soubeyroux, Pauperisme, esp. i. 1967: “En dépit des ordonnances interdisant l'entrée des femmes dans les tavernes, le cabaret ne semble donc pas avoir été à Madrid le cadre d’une sociabilité exclusivement masculine. Les femmes, quoique très minoritaires, se mêlaient aux hommes.”

${ }^{29}$ Gemeindearchiv Neuenegg, Chorgerichts-Manual 1.1, 31 March 1650 ("Hans Flu(e)man sampt sÿnem Ehewÿb, zu(o) Wÿden: wegen langes übersitzens v. wÿntrinckens im Wirthshus". Hans failed to stop "seine hußfrauw nit ernstlich von zu(o) viler wirthshus besuchung”) and 13 February 1681 (“Elsi Herren hat im Wihrtshaus gedantzet ist wie andere belegt vmb x schl.”); for information on the context cf. Sittenregeln Menschen(ge)recht? Das Neuenegger Chorgericht, ed. Elisabeth Bachofen and Hans Marschall (Neuenegg, 1998), 174, 188.

${ }^{30}$ Bennett, Ale, Beer and Brewsters in England, passim; Clark, Alehouses, 82-84; Radeff, Café dans le chaudron, 216; for a general account of women's role in the drinks trade see Merry E. Wiesner, Women and Gender in Early Modern Europe (Cambridge, 1993), 96. ${ }^{31}$ The database is based primarily on the information of the registers of inns and taverns in the StA BE (B V 142-148), but includes references from many other types of documents. 
Legal historians usually list manorial lords, monasteries or state authorities as owners of inns and taverns, ${ }^{32}$ but in Central Europe, at least, there was a surprising amount of local - and particularly communal - influence. ${ }^{33}$ Scores of towns and villages (some 265 in Northern Switzerland and on the Upper Rhine alone) possessed their own establishment, so-called Stuben or Maisons de Ville, which they let out at the best possible rate, making sure that prospective tenants would provide all the required services. ${ }^{34}$ Throughout the Bernese territory, furthermore, provincial towns regulated their hostelry trade independently. In 1743, Nidau near Biel "produced an extract from a privilege by their lords of 3 February 1448 which allowed the town to appoint and dismiss their own innkeepers, taverners and butchers," ${ }^{35}$ while the customs of the Pays de Vaud specified that "city councils were empowered to permit anybody considered suitable to hold a public hostelry" and that they "had full authority to supervise all hosts or keepers of taverns." Aubonne, like dozens of other local communities, confidently referred to "the freedom and right .... specified on fo. 27 of the book of customs" whenever their policy was challenged by central authorities. ${ }^{36}$ Rural areas, too, exercised considerable influence. Countless

${ }^{32}$ The best study of the economic and legal framework is Johanna Kachel, Herberge und Gastwirtschaft in Deutschland bis zum 17. Jahrhundert (Stuttgart, 1924). The standard works on the legal framework for Bernese inns and taverns are Moritz von Stürler, "Die konzessionierten Wirtschaften im Kanton Bern,” Berner Zeitschrift für Geschichte und Heimatkunde 37 (1975), 19-27, and Markus Escher, “Das Recht des Gastgewerbes im alten Bern” (Ph.D. Freiburg i.Ü., 1977).

${ }^{33}$ Beat Kümin, “Rathaus, Wirtshaus, Gotteshaus. Von der Zwei- zur Dreidimensionalität in der frühneuzeitlichen Gemeindeforschung,” Colloquium mediaevale Pragense, ed. Thomas Krzenck (Prague, forthcoming).

${ }^{34}$ Albrecht Cordes, Stuben und Stubengesellschaften. Zur dörflichen und kleinstädtischen Verfassungsgeschichte am Oberrhein und in der Nordschweiz (Stuttgart, 1993), 229-316, lists 265 institutions belonging to the Gemeinde or other local bodies.

${ }^{35}$ StA BE, B V 144, 74 (“Die Stadt produciert Extract Freÿheits Brieff von MngH und Oberen de 3. Febr. 1448 darin Jhnen bewilliget wird Tavernen und Pintenschenk Wihrten wie auch die Mezgern besezen und entsezen ze können”; 1743).

${ }^{36}$ Les Loix et Statuts du Pays de Vaud et les Principales Ordonnances \& Mandats Souverains, Avec un Répertoire trés exact (Bern, 1730), fos. 26-31 ("Le conseil de châque Ville pourra ottroyer, \& permettre à tous ceux que bon luy semblera \& qu'il jugera propres \& capable de lever \& tenir Taverne \& Hôtelerie publique avec enseigne” and “Tels 
villages in the French lands owned a tavern run by the local mayor and according to undisputed privileges, the heads of households of the Bernese Oberland appointed their own innkeepers in periodical assemblies of the regional courts. ${ }^{37}$

From the point of view of numbers, locations, patrons and owners, therefore, inns and taverns appear as ubiquitous, conveniently located and broadly accessible establishments, which answered to local as well as central concerns.

Turning to the range of activities, the first point to make is the fact that inns and taverns from the earliest origins in the twelfth and thirteenth centuries - were remarkably versatile institutions. ${ }^{38}$ The following survey of an "ideal type" hostelry distinguishes five major uses for the local and wider community, without claiming that all institutions fulfilled all these functions at all times. Size, location, status and socio-economic circumstances, of course, affected the role of a particular establishment in a given historical context.

The first and foremost purpose of a hostelry was the provision of a set of core services: drink, bread and cheese in ordinary taverns, a wider selection of food, overnight accommodation, stable room for horses and (from the later sixteenth century) access to transport or postal facilities in the case of inns. There was little privacy for the visitors, for all of them ate together and - sometimes up to the eighteenth century - slept in the same room, if not the same bed! ${ }^{39}$ Upon closer inspection public eating and drinking appear as

Conseils ésdittes Villes \& Communes auront plein pouvoir \& authorité, de régler les ... Hôtes, ou Taverniers vendants vin à pinte”). The quote regarding Aubonne in StA BE, B V 144, 13 (“Freÿheit und Rechtenn ... vermög Contumier fo. 27”; 1743).

${ }^{37}$ See e.g. StA BE, B V 144, 32 (Frutigen in the Bernese Oberland), 68 (many examples from the Pays de Vaud).

${ }^{38}$ The earliest evidence for commercial hospitality dates from the twelfth and thirteenth centuries: Peyer, Gastlichkeit, 281; Chartres, “English inns,” 160, 176. Bartlome, Rechnungsbücher, illustrates the remarkable range of activities of a medieval innkeeper. ${ }^{39}$ Evidence for fixed menus served at fixed times for a fixed price (table d'hôte-system) as well as shared bedroom accommodation appears in all general surveys such as Potthoff and Kossenhaschen, Kulturgeschichte der deutschen Gaststätte. Innkeepers played a major role in the stage coach business: Chartres, “English inn,” 175. For informal postal services by carriers: Michael Frearson, "Communications and the continuity of dissent in the Chiltern Hundreds during the sixteenth and seventeenth centuries,” The World of Rural Dissenters 1520-1725, ed. Margaret Spufford (Cambridge, 1995), 273-87, esp. 283. For Bern: Hans Müller, "Die Fischersche Post in Bern in den Jahren 1675-98," Archiv des Historischen 
powerful rituals, governed by well-established conventions. Personal honour, for instance, was very easily violated by snap comments in front of other guests, by the refusal to drink someone's health or the failure to buy wine when joining a group of people sitting at a table. Many business deals, contractual agreements and personal relationships, furthermore, were symbolically confirmed by means of a drink at the tavern. ${ }^{40}$

Secondly, inns and taverns offered all sorts of entertainment. The basic attraction, of course, was alcohol, and we are not short of colourful anecdotes about the ensuing excesses. It is hard to find a contemporary illustration without a peasant vomiting (or engaging in other indecent activities) somewhere in a corner. ${ }^{41}$ The same sources, however, also record the presence of musicians, singers, magicians and jesters, while commercially astute landlords invested in the staging of plays and other cultural events to boost turnovers. ${ }^{42}$ Games and gambling were equally popular, in spite of government restrictions.

Vereins des Kantons Bern 24 (1918), 1-188, esp. 45, and Arthur Wyss, Die Post in der Schweiz. Ihre Geschichte durch 2000 Jahre (Bern, 1987), esp. 88-89, 109.

${ }^{40}$ The rituals and theatrical elements of public consumption are discussed in Hürlimann, “Öffentlicher Konsum,” esp. 152-156, and Brennan, Public Drinking, 16-19; for tavern conflicts cf. also Hohkamp, “Wirtshaus;” for confirmation of legal and economic agreements by means of a drink of wine: Liebenau, Wirtshauswesen, 260, 264.

${ }^{41}$ See e.g. figure no. 133 in Walter Salmen, Der Spielmann im Mittelalter (Innsbruck, 1983); Taverns were places, “où les hommes cherchent, par exemple, à faire rire les autres en pissant dans le chapeau du voisin, ou expriment l'excès en vomissant sur des endroits mal choisis”: Robert Beck, Histoire du Dimanche. De 1700 à nos jours (Paris, 1997), 80; "Es sol auch kainer uf oder in gmainer stuben kain reüpsten oder koppen noch furtz lassen, also das es erhalle, auch nit pruntzen uff oder in bgriff der stuben, welcher das verpricht, pessert VI d.”: Regulations for the Stube at Mittelweier of 1530, cited in Cordes, Stuben, 201.

${ }^{42}$ From the late Middle Ages, inns and taverns provided common venues for travelling musicians in Central Europe: Jürgen Brandhorst, “Spielleute. Vaganten und Künstler,” Randgruppen der spätmittelalterlichen Gesellschaft. Ein Hand- und Studienbuch, ed. Bernd-Ulrich Hergemöller (2nd edn., Warendorf, 1994), 157-180, esp. 165; for a contemporary account of the range of entertainments cf. Erasmus, “Diversoria,” and see figures nos. 47 and 109 in Salmen, Spielmann im Mittelalter. Initiatives by landlords are highlighted in Alan Everitt, “The English urban inn 1560-1760,” Perspectives in English Urban History, ed. Idem (London, 1973), 114-120. 
The regulations of the Stube of Waltershofen near Freiburg i.B. from 1491 imposed fines for cheating and failing to pay one's gambling losses, while the Bernese authorities banned some types of games altogether. As late as 1748 , four men were punished for playing cards in the Bear inn at rural Neuenegg, even though a mere measure of wine had been at stake. ${ }^{43}$ Sex provided further temptations. It has been argued that secluded rural taverns acted as prototypes for more institutionalized brothels in towns, ${ }^{44}$ and borderlines between the two types of establishment remained blurred throughout our period. ${ }^{45}$ After an unsuccessful petition against competition by women operating from regular hostelries in 1492, prostitutes of an official Nuremberg brothel stormed a number of suspicious establishments in 1505 and $1538 .{ }^{46}$ The oath taken by Bernese landlords in 1617 in turn emphasized the need for vigilance against "whores ... and particularly people infected with the French and other diseases," while the newly emerging coffee houses soon acquired a reputation for easy access to sexual services. ${ }^{47}$ This put landladies, waitresses and female servants in a delicate position. In some places, courts refused to consider their charges simply on the grounds of their disreputable profession, and many a guest exploited the situation. ${ }^{48}$ Even some clergymen struggled to live up to their ideals. Consistory court records from 1654 report the case of the minister Daniel Schaffner from Eggiwil in the Emmental, who was

${ }^{43}$ Cordes, Stuben, 218 (Waltershofen); Neuenegger Chorgericht, ed. Bachofen and Marschall, 186. For repeated ordinances restricting games and gambling see Bern in seinen Rathsmanualen 1465-1565, ed. Berchtold Haller (3 vols., Bern, 1900-1902), ii. 325-328. ${ }^{44}$ Annette Lömker-Schlögell, "Prostituierte - 'umb vermeydung willen merers übels in der cristenhait'," Randgruppen, 56-88.

${ }^{45}$ Robert Jütte, Poverty and Deviance in Early Modern Europe (Cambridge, 1994), 65; Erica-Marie Benabou, La prostitution et la police des moeurs au XVIII siècle (Paris, 1987), 68. See the tavern-cum-brothel in a painting by the sixteenth-century Dutch master Jan Sanders van Hemessen reproduced in Benker, Gasthof, no. 325.

46 Theodor Hampe, Die fahrenden Leute in der deutschen Vergangenheit, mit Beilagen nach den Originalen des 15. bis 18. Jahrhunderts (Leipzig, 1902), 64.

${ }^{47}$ Stadtrechte, vol. VIII/1, ed. Rennefahrt, 205-7 (“hu(e)ren ... und insonderheit persohnen, so mit frantzosen oder anderen erbsuchten behafft”); Hans-Jürgen Teuteberg, “Die Eingliederung des Kaffees in den täglichen Getränkekonsum,” Unsere tägliche Kost. Geschichte und regionale Prägung, ed. Idem and Günter Wiegelmann (2nd edn., Münster, 1986), 185-201, esp. 190.

${ }^{48}$ Beneder, Männerort Gasthaus?, 130, 184; Wiesner, Women, 96. 
charged for the fact that he had "molested the maid servant at the front and at the back and that the landlady had placed her hand into his fly." 49

Thirdly, inns and taverns served as focal points for contacts with the outside world, enabling quite intimate encounters between locals and strangers. In a rather touching memory from his visit to the Valais, an early modern traveller recalled a young mother breast-feeding in a mountain inn, which struck him as the "most beautiful and moving symbol of love." 50 The comings and goings of pedlars, carriers, merchants and foreign envoys established hostelries as "crucial intersecting points in the communications network" between the locality and the wider world. ${ }^{51}$ In their capacity as "news rooms" of early modern society, ${ }^{52}$ they fostered the exchange of rumours and gossip,,$^{53}$ but also serious debate. One of the carnival plays by the sixteenth-century Bernese poet and politician Niklaus Manuel includes the resigned comment of a senior churchman: "Whenever I meet peasants in a tavern, they at once start to argue, and if I want to reason with them about the clergy's importance, they exclaim: prove it by Scripture, namely biblical truth and not Roman trickery." 54 Some establishments acquired a distinctive confessional flavour, be it the anti-Zwinglian Red Sword in 1520s Zurich or the Bull and

${ }^{49}$ Cited in Urs Hostettler, Der Rebell vom Eggiwil. Aufstand der Emmentaler 1653. Eine Reportage (Bern, 1991), 720-721 (“die Magd vornen und hinden gegriffen und die Frau Wirtin habe ihm ihre Hand in den Hosenladen ghan”).

${ }^{50}$ Carl Gotthard Grass, “Tagebuch einer Wanderung," Fragmente von Wanderungen in der Schweiz (Zurich, 1797), 154 (“das schönste rührendste Simbol der Liebe”).

${ }^{51}$ Frearson, “Communications,” 283.

52 Everitt, “English urban inn,” 91-137, esp. 112; similar assessments in Teuscher, Soziabilität, 195, and Richard Cust, "News and politics in seventeenth-century England,” Past and Present 112 (1986), 60-90, esp. 65-66.

${ }^{53}$ Bob Scribner, “Oral culture and the diffusion of Reformation ideas,” Popular Culture and Popular Movements in Reformation Germany, ed. Idem (London, 1987), 49-69, esp. 57-59.

${ }^{54}$ Niklaus Manuel, ed. Jakob Baechtold (Frauenfeld, 1878), 47 (“Wo ich im wirtshus zu(o) [Bauern] kum, / So hebend sie an zu(o) arguwieren; / Wil ich denn mit inen disputieren / Das, so unseren nutz antrifft, / So sprechend s': erzeig's mit gschrift, / Und namlich die recht biblisch si / Und nit mit röm’scher büebery”). 
Mouth inn near London’s Aldersgate, meeting-point of the city’s Quakers in the midseventeenth century. ${ }^{55}$

Fourthly, hostelries constituted places of manifold economic and personal opportunities. Visitors appreciated the availability of credit, storage and trading facilities, ${ }^{56}$ the ready information about job vacancies or recruitment to military service ${ }^{57}$ and the possibility of encountering prospective patrons. In many of these personal relationships, landlords acted as powerful mediators or brokers. No other profession in the early modern period, apart from the clergy, possessed a comparable range of contacts or better facilities to bring people together and to know what was going on. ${ }^{58}$ The same sort of opportunities, however, were appreciated by the criminal underworld. There is an entire literary genre, dedicated to murderous landlords and hostelries as haunts of offenders. ${ }^{59}$ The spectrum of wrongdoings ranged from petty alcohol-inspired violence, as in Neuenegg in 1678, where "Peter Freiburghaus, elder and court official, treated the village teacher Schwendimann in a most inhumane fashion, for when the latter slept on a chair, the official - who was drunk grabbed him by his feet and pulled him from the chair so that he hit his head on the floor and then dragged him around the room," up to early forms of organised crime such as the

${ }^{55}$ Peyer, Gastlichkeit, 257; Frearson, “Communications,” 276, 286.

${ }^{56}$ Wilfried Kerntke, Taverne und Markt. Ein Beitrag zur Stadtgeschichtsforschung (Frankfurt, 1987).

${ }^{57}$ Teuscher, Soziabilität, 194-195. Inns and taverns themselves absorbed a substantial part of the labour force (as waiters, servants, chamber maids, cooks etc) and may have constituted the largest unit of industrial plant outside dockyards and mines before the Industrial Revolution: Chartres, “English inn,” 173.

${ }^{58}$ Ulrich Pfister, "Politischer Klientelismus in der frühneuzeitlichen Schweiz,” Schweizerische Zeitschrift für Geschichte 42 (1992), 28-68, esp. 36.

${ }^{59}$ Contemporary examples include The Bloody Innkeeper, or Sad and Barbarous News from Gloucestershire (1675), the French seventeenth-century tract Histoire merveilleuse et véritable des homicides, voleries, et assassinats ... commis par le Capitaine la Noye or a passage in the first German prose novel Fortunatus (1509). For a more recent representative of the genre, set in the Schwarenbach inn on the Gemmi pass between Bern and the Valais, cf. Zacharias Werner, Der vierundzwanzigste Februar (Grimma, 1841). 
gangs of highwaymen who used isolated taverns as bases for their raids. ${ }^{60}$ At Lausanne in our case study, the Ville de Paris was closed by the authorities in 1786 as a haunt for common thieves, while 54\% of those arrested for stealing food in eighteenth-century Paris lived in innkeepers' rooms or similar accommodation. ${ }^{61}$

Fifthly and finally, inns offered a venue for political assemblies and other public business. According to a recent study of sociability in pre-Reformation Bern, they constituted particularly important places of short-term association, which were well suited "for the rapid transformation of previously loose personal relations into powerful political factions." ${ }^{62}$ Many towns and villages, as mentioned above, possessed their own Stube to deal with matters of public concern. According to the oath of the elected Stubenmeister of Börsch near Strasbourg, in 1547, the official was ordered not to overcharge people, "particularly at Christmas and whenever town councillors, courts or assemblies of the whole community meet in the stube to eat and drink together." ${ }^{63}$ In the Vaud, no fewer than 27 Maisons de Ville fulfilled similar functions, while at Ormont-Dessus court and communal assembly used the Bear for their gatherings. ${ }^{64}$ Given the shortage of public buildings in many places, inns met further needs such as the staging of auctions or the detainment of sureties until the settlement of all outstanding debts. Local authorities, in turn, appreciated hostelries as entertainment facilities for their official guests, but also as

\footnotetext{
${ }^{60}$ Neuenegg, Chorgerichts-Manual 1.2, 10 March 1678 ("Peter Frÿburghaus der Weibel ... mit dem Schu(o)lmeister Schwändimann im Wihrtshau(o)s gar vnmenschlich gehandlet, da er vff ein stull geschlaffen kompt der Weibel truncken vnd nimpt ihn bÿ den füßen vnd zücht ihne ab dem Stu(o)ll das er den hau(o)pt vff den boden gschlagen, hernoch in der stuben herumb gezogen”); similar evidence in Bernhard Müller-Wirthmann, "Raufhändel.
} Gewalt und Ehre im Dorf,” Kultur der einfachen Leute, ed. Richard van Dülmen (Munich, 1983), 81. For inns and taverns as meeting-points of bandits cf. Rauers, Kulturgeschichte der Gaststätte, 812-820.

${ }^{61}$ Radeff, “Réseau,” 134 (Lausanne); Jütte, Poverty and Deviance, 66 (Paris).

${ }^{62}$ Teuscher, Soziabilität, 267-68 (inns being suited "für die rasche Rekrutierung und Integration von zuvor nur lose miteinander verbundenen Personen zu politischen Faktionen”). The importance of social drinking for the formation of a "structural identity" among industrial workers is emphasized by Brennan, Public Drinking.

${ }^{63}$ Cordes, Stuben, 173 (“sonderlich zu wyhenachten und so ein rath und gericht oder eine gantze gemeindt uff der stuben bey einander sindt, und zeeren”).

${ }^{64}$ Radeff, “Réseau,” 131. 
intelligence centres and even temporary prisons. ${ }^{65}$ The very same places, on the other hand, could turn into breeding-grounds for political unrest and outright rebellion. During the English occupation of France in the early fifteenth century, Henry V closed 26 Paris taverns as focal points of resistance, and some 100 years later, German authorities proved equally worried: following a series of peasant risings in the Empire, taverns were ordered to shut as early as at eight o'clock in the evening to prevent nightly assemblies of the rabble or Pöbel. ${ }^{66}$ Given their contacts and local influence, landlords were natural ringleaders. Many Bernese innkeepers, for instance, played an active part in the Swiss' peasants war of 1653, from Hans Buri of the Lion at Attiswil to Christen Zimmermann of the Star at Guggisberg. ${ }^{67}$

Inns and taverns thus encroached on the preserves of a number of other local institutions, namely, an individual's family or kin in the field of inter-personal relations, educational establishments and printing presses in terms of widening peoples' horizons, market-squares in terms of trading goods, town halls with regard to political decisionmaking, ${ }^{68}$ and churches in the religious realm. ${ }^{69}$ All this turned the local inn into the single most important social centre in the post-Reformation period. ${ }^{70}$ Compared to early modern

${ }^{65}$ Details concerning these functions in Peyer, Gastlichkeit, chapter 3.5; and Tlusty, “The Devil's Altar," chapter 2.

${ }^{66}$ Alfred Gottschalk, Histoire de l'alimentation et de la gastronomie. Depuis la préhistoire jusqu'à nos jours (2 vols., Paris 1948), i. 320; Peter Blickle, “The criminalization of peasant resistance in the Holy Roman Empire. Toward a history of the emergence of high treason in Germany,” Journal of Modern History 58 (Supplement, 1986), S88-S97, esp. S95 (with references to early sixteenth-century ordinances).

${ }^{67}$ At the current stage of compilation, the author's database of early modern Bernese landlords includes 14 participants in the rebellion.

68 Teuscher, Soziabilität, 200, describes inns as a "Gegenpol zum Rathaus.”

${ }^{69}$ Robert Muchembled, L'invention de l'homme moderne. Sensibilités, moeurs et comportements collectifs sous l'Ancien Régime (Paris, 1988), 204-205, sees the tavern as a “concurrent de l'église."

${ }^{70}$ For Radeff, "Réseau,” inns were “indispensables ... à tous les niveaux sociaux;” Clark, Alehouse, 27-34, and Cordes, Stuben, 337, share the view that they replaced the parish church as the chief social centre by the mid-sixteenth century; for Chartres, "English inn," 175 , however, "the inn was second only to the church in importance as an urban institution.” 
churches and town halls, both of which suffered a relative loss of importance and autonomy as a result of confessionalization and the rise of territorial states, they distinguished themselves by their multifunctional character, permanent accessibility and relatively informal contacts with other social groups as well as the outside world. Here we look in vain for clear-cut borderlines between the social, economic, religious and political spheres.

(ii)

But why should the hostelry trade be difficult to govern? Was there not, ever since the late Middle Ages, a flood of regulation in all imaginable areas, from opening hours, indirect taxes, range of services and the level of prices through to the banning of certain games or entertainments and the landlords' duty to report passing strangers? ${ }^{71}$ Are early modern states not famous for their attempts to discipline and civilize all subjects? ${ }^{72}$ Even in the face of such undeniable pressures, however, inns and taverns proved surprisingly resilient. Two observations may help to substantiate this point: First, in spite of explicit government efforts to reduce the number of establishments, more and more seem to have emerged in the course of the early modern period. Second, the great body of rules and regulations met with only very partial acceptance at the local level.

A first indication is the gradual increase in numbers. The quantitative information shown in Figures 1-2 derives from the official registers compiled by the Bernese authorities in 1628, 1688, 1743 and 1786 . It is important to emphasize, therefore, that the

${ }^{71}$ A compilation of relevant rules for the state of Bern in Stadtrechte, vol. VIII/1, ed. Rennefahrt, 198-255; for England cf. Judith Hunter, “Legislation, royal proclamations and other national directives affecting inns and taverns, alehouses, brandy shops and punch houses 1552-1757” (Ph. D. Reading, 1994); for the Holy Roman Empire cf. the individual volumes of the series Repertorium der Policeyordnungen der frühen Neuzeit, ed. Michael Stolleis and Karl Härter.

${ }^{72}$ Norbert Elias, The Civilizing Process, trans. Edmund Jephcott (2 vols., Oxford, 197882); England remains a model case for such a campaign: Keith Wrightson, “Alehouses, order and reformation in rural England 1590-1660,” Popular Culture and Class Conflict 1590-1914, ed. Stephen and Eileen Yeo (Brighton, 1981), 1-27. Augsburg taverns, it has been suggested, “aided the authorities in exerting control over the populace:” Tlusty, "The Devil’s Altar,” 185-186. 
trends need to be interpreted with some caution: certain institutions were probably overlooked by the surveys, some regions may have been more thoroughly investigated than others and there are no reliable figures at all for the countless informal drink outlets selling the burghers' own produce.

Figure 1: Development of the number of hostelries in the German lands of the old Republic of Bern (incl. Bernese Aargau) 1628-1786 ${ }^{73}$

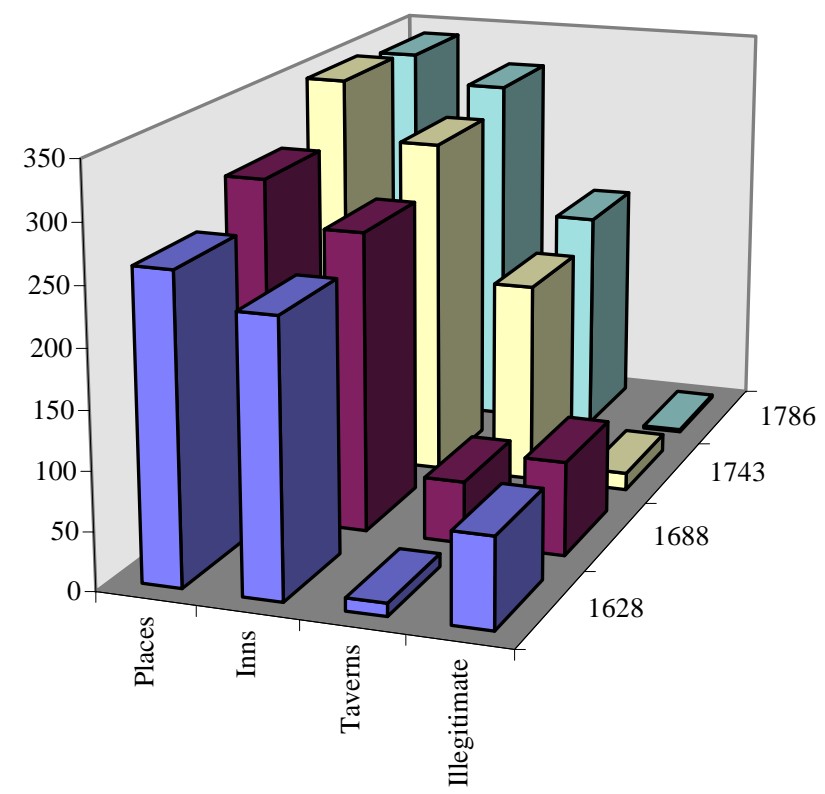

Figure 2. Development of the number of hostelries in the French lands of the old Republic of Bern 1628-1786 (no information survives for 1688) ) $^{74}$

${ }^{73}$ The graphs are based on the author's database of the information contained in StA BE, B V 142, 143, 144 and 148, passim; "places” = number of towns, villages and hamlets with hostelries mentioned in the registers; "illegitimate" = "Winkelwirtschaften" earmarked for closure.

${ }^{74}$ Based on StA BE, B V 142, 144 and 148, passim; the 1786 register for the French part distinguishes between - a roughly similar number of - hostelries for mounted travellers on the one hand and for pedestrians on the other (both subsumed under “inns"). 


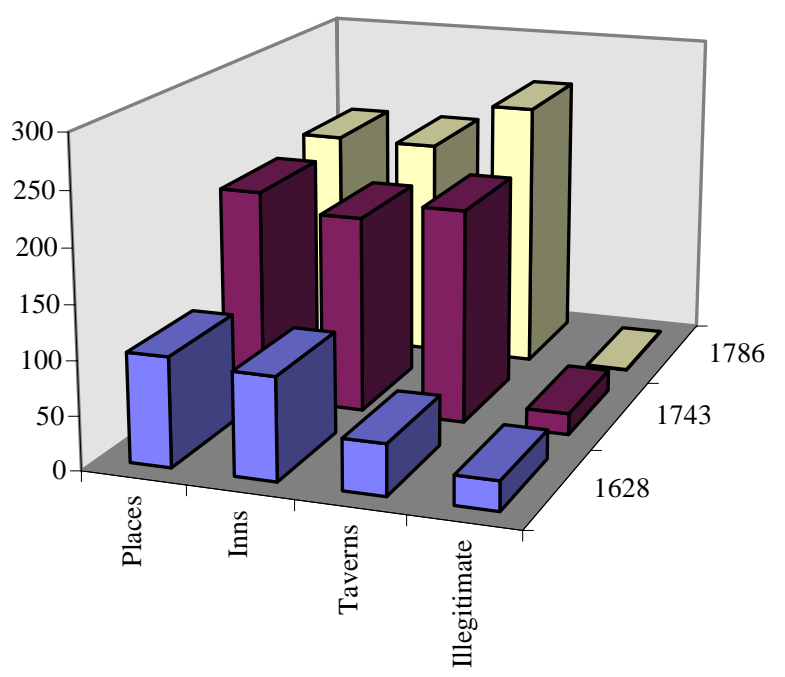

Keeping methodical reservations in mind, the overall impression is one of a striking and sustained increase over the whole period, from a grand total of just under 500 institutions in 1628 to 1015 in 1786. The number of hostelries was also distributed over more and more different places. The steady fall in institutions deemed "illegitimate" and earmarked for closure symbolizes the difficulties facing the government's long-standing campaign to restrict numbers. The registers, it seems, gradually lost their original purpose (i.e. the identification of superfluous inns and taverns) and became mere stock-taking exercises. In both figures, we can observe an extraordinary leap in the provision of taverns between the early seventeenth and mid-eighteenth centuries, in the Vaud also in terms of inns. The latter at least is unlikely to be an optical illusion created by more efficient official searches, for inns had always been very conspicuous establishments based on specific legal rights (so-called ehafte Rechte tied to particular pieces of land). Detailed explanation of these trends must await further local research, but it is tempting to relate this growth not only to rises in population, ${ }^{75}$ but also the recent scholarly emphasis on the surprisingly dynamic economy in the western part of the Swiss Confederation towards the end of the Ancien Régime, even in rural contexts and particularly in the Vaud. Our case studies may not have

\footnotetext{
${ }^{75}$ The growth rates for the Vaud described in Mattmüller, Bevölkerungsgeschichte der Schweiz, i. 121-122, are certainly much less pronounced than the increase in the provision of hostelries observed here.
} 
been at the vanguard of protoindustrial development, ${ }^{76}$ but periods of good harvests between 1635-90 and in the first half of the eighteenth century, ${ }^{77}$ widespread viniculture, extensive road-building programmes, a dense network of towns, considerable expansion in the number of weekly and seasonal markets as well as business generated by early tourism probably supported the upward trend in this period. ${ }^{78}$ The old German part, a traditional agricultural area with comparatively fewer markets, ${ }^{79}$ lived up to its time-honoured image of proceeding at a more leisurely pace: sustained growth in absolute numbers, but from a higher starting-point and with less dramatic intermediate increases. The French-speaking inhabitants, regardless of their political subjection to Leurs Excellences de Berne, enjoyed rather more expansion than the core German lands.

Persistent growth in the hospitality trade, however, was not just a reflection of socio-economic factors, but also a distinct lack of co-operation with official restrictions. Instructions to abolish particular establishments, for example, were often ignored. At Langnau in the Emmental, only one landlord was formally approved in the early seventeenth century, but subsequent reviews found that "two had always remained there." The communal inn at L'Isle in the Vaud was earmarked for closure in 1628, but existed "since time immemorial" according to a survey in 1743, whilst the tavern of Attiswil, the Bear inn at Münsingen or the third hostelry at Sarraz were forbidden at various times, but "always remained thereafter." ${ }^{80}$ Reading official declarations by Bernese authorities, there is a strong sense of desperation about the persistent growth in the drinks trade: Having instructed local officials to suppress all "unnecessary and illegitimate establishments on

${ }^{76}$ Ulrich Pfister, "Proto-industrialization in Switzerland,” European Protoindustrialization, ed. Sheilagh C. Ogilvie and Markus Cerman (Cambridge, 1996), 137154, esp. 138.

${ }^{77}$ Martin Körner, “Glaubensspaltung und Wirtschaftssolidarität 1515-1648,” Geschichte der Schweiz und der Schweizer, ed. Beatrix Mesmer (3 vols., Bern, 1983), ii. 7-96, esp. 21, and François de Capitani, “Beharren und Umsturz 1645-1815,” ibid., 97-175, esp. 108.

${ }^{78}$ Summarizing Radeff, Café dans le Chaudron, 425-428; Jean-Pierre Dewarrat and Laurence Margaisaz, “Le Pays de Vaud. Lieu de passages,” De l'Ours à la Cocarde, 45-57, esp. 56.

${ }^{79}$ Radeff, Café dans le Chaudron, 462.

${ }^{80}$ StA BE, B V 143, 20 (“sind aber stäts zweÿ gebliben”); B V 144, 68 (“seit undenklichen Zeiten”); B V 148, 3, 20, 31 (“ist aber seither geblieben”). 
pain of large fines and imprisonment” in $1571,{ }^{81}$ the authorities complained about the fact that "nearly everybody wanted to run an inn or tavern" in the mid-seventeenth century, ${ }^{82}$ only to perceive the need for a further clampdown "because of the ever-increasing vice of drunkenness throughout the country" one hundred years later. ${ }^{83}$ Part of the problem lay in the fact that legitimate public demands for further hostelries forced the government to suspend its restrictive policy again and again. The tavern at Bettenhausen near Burgdorf, for instance, identified as one of many "harmful” institutions during a review in 1688, had been set up with official permission in $1679 .{ }^{84}$

Another approach to measure the quantitative importance of inns and taverns is the analysis of per capita ratios. Catholic areas, with their very extensive ceremonial culture, reached impressive figures: 1 hostelry per 447 inhabitants in late eighteenth-century Madrid, 1:200 in 1790s Paris, right down to a remarkable 1:25 in certain Bavarian pilgrimage centres. ${ }^{85}$ The state of economic development, of course, played an equally important part. Protestant Appenzell Ausserrhoden in north-eastern Switzerland, a heavily protoindustrialized area with many workers disposing of a little spare cash to spend at the tavern, maintained on average 1 establishment per 180 souls in 1726, with rapid further

${ }^{81}$ The motive was the need to "prevent our subjects from wasteful consumption and to get them used to honest work and good housekeeping”: Stadtrechte, vol. VIII/1, ed.

Rennefahrt, 199-200 (“unnothwendige wirts und winckelhüser by uffsatz hocher straff an gelt und der gevencknus abgeschafft", with the intention "hiedurch die unseren dester ee von söllichem überflüssigen prassen und zeeren ab, und zu(o) erlicher arbeit und gu(o)ter hußhaltung gewöndt werdind”).

${ }^{82}$ Quote from an ordinance of 14 October 1665: StA BE, A I 486, 364 (“dass bald jeder sich des Pintenschenkens und Wirthens underfangen will”).

${ }^{83}$ Stadtrechte, vol. VIII/1, ed. Rennefahrt, 210-211 (“weil das verderbliche laster der trunkenheit samt seinen traurigen folgen auf dem land immer zunehme”). Much similar evidence survives for other European regions: Radeff, Café dans le chaudron, 226; Soubeyroux, Pauperisme, i. 195.

${ }^{84}$ StA BE, B V 143, 26.

${ }^{85}$ Soubeyroux, Pauperisme, 195 (1797); Beck, Dimanche, 79; Peter Hersche, “Die Lustreise der kleinen Leute - zur geselligen Funktion der barocken Wallfahrt,” Geselligkeit und Gesellschaft im Barockzeitalter, ed. Wolfgang Adam (Wiesbaden, 1997), 321-332, esp. 326. 
growth in the course of the eighteenth century. ${ }^{86}$ The Republic of Bern, a much less economically advanced protestant region, reached a more moderate average ratio of 1 inn or tavern per 394 inhabitants in 1786 (down from 425 in 1628), varying between 1:471 in the German lands and 1:302 in the Vaud. These last figures suggest that the government campaign achieved a certain effect in the core areas of its territory, over which it exercised tighter control, boosting the number of inhabitants per hostelry from 1:369 in 1628 to 1:471 in 1786, but that it failed completely in the French lands, where the ratio worsened from an official point of view - from 1:532 in the early seventeenth to 1:302 in the late eighteenth century. Strong communal privileges, competing powers by other feudal lords and plentiful provision of local wine presented particularly high obstacles in the Pays de Vaud. ${ }^{87}$ Whether the council of Bern was aware of its partial success remains more than doubtful. What counted for its members, judging from their continuous complaints, was the obvious growth in absolute numbers throughout the country.

A comparative glance at present-day conditions yields interesting results. Figure 3 displays the respective figures (for inns and hotels only) in 1786 and 1996. In spite of all the methodological difficulties of such an exercise, above all our ignorance of the relative size of pre-modern institutions, it is clear from this graph that inns were remarkably prominent in the Ancien Régime.

Figure 3. Number of inhabitants per inn / hotel in the German and French lands of the old Republic of Bern in 1786 compared to the present-day Cantons of Bern and Vaud in $1996^{88}$

${ }^{86}$ Tanner, Spulen, table 68.

${ }^{87}$ Cf. the overlord of Chapelle's confident claim in 1743 that "he was allowed to establish inns at his own free will” (StA BE, B V 144, 71; “und allso erlaubt seÿe nach belieben und gutfinden Tavenen zu besezen”).

${ }^{88}$ Absolute numbers of 314 inns for the German part and 209 for the Vaud from StA BE, B V 148, passim (1786), and Statistisches Jahrbuch der Schweiz, ed. Bundesamt für Statistik (Bern, 1998), 298 (861 hotels in Bern and 404 in the Vaud in 1996; ibid., 70: population of 941,000 for Bern and 606,000 for Vaud in 1996); the population count at the end of the Ancien Régime was carried out at a slightly later date than the register of inns (1798 instead of 1786), but very few institutions emerged in the intervening twelve years (there were 140,000 inhabitants in the French part according to Lucienne Hubler, "La population sous l'Ancien Régime. La vie fragile,” De l'Ours à la Cocarde, 61-72, esp. 62; the figure of 400,000 inhabitants for the entire Republic of Bern in Pfister and Egli, Historisch-Statistischer Atlas, 34, suggests 260,000 for the German lands). To facilitate 


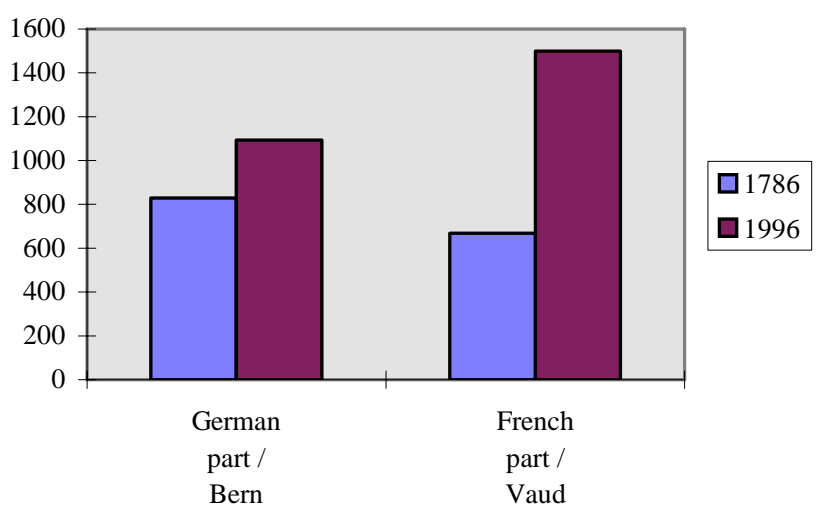

Per heads of population, at least, there are fewer institutions today than there were at the close of the eighteenth century. The French-speaking region of the Vaud again appears as an area with particularly dense early modern provision and a rather more marked difference in the ratio compared to the situation in the present-day canton.

The high number of hostelries, however, was not the only difficulty encountered by early modern legislators. The German estates admitted further problems in June 1670: "Even though certain ordinances concerning prices in hostelries were set up in the Reformation of Good Police by the Imperial Diet of Augsburg in 1530, it is apparent that they are not respected, so that guests and other people, who are forced to travel, are much burdened." ${ }^{89}$ The Bernese council conceded at about the same time that repeated ordinances against Sabbath-breaking had failed to achieve the desired effect, ${ }^{90}$ and the ban comparison, those areas in the present-day Canton of Vaud which belonged to the German lands for administrative purposes, are here included in the French part of the old Republic. ${ }^{89}$ Decree by the Imperial Diet of 16/26 June 1670, in Neue und vollsta(e)ndigere Sammlung der Reichs=Abschiede, IV. Teil, ed. Ernst August Koch (Frankfurt a.M., 1747), 79 (“Obwohlen auch ... in der Anno 1530 zu Augspurg aufgerichteten Reformation guter Policey, Tit. 25. Wegen der Zehrung bey den Wirthen, bereits gewisse Verordnung enthalten; so befindet sich jedannoch, daß derselben nicht nachgegangen, sondern den Ga(e)sten, und anderen, so die Strassen gebrauchen mu(e)ssen, viel Beschwerung zugefu(e)gt wird”).

${ }^{90}$ According to a fresh mandate of 1654 which the minister copied on the back pages of Neuenegg, Chorgerichts-Manual 1.1 (“darwider wir zwar schon zu(o) vnderschiedlichen mahlen ernstliches verbot vßgahn laßen; welches aber ... anderst nit gefruchtet, ... dann daß solich vnwesen je länger je mehr zu(o): ja gar überhandt nimbt”). 
on dancing, in force from the Reformation up to the mid-eighteenth century, proved equally difficult to uphold. A quantitative survey of offences censured by a number of parish courts reveals steady and by no means decreasing evidence for illegitimate dancing at inns as well as other locations, very probably with the tacit permission of local elders. 265 people were charged with dancing in the parish of Vechigen in 1664 alone! ${ }^{91}$ Persistent complaints about unacceptable behaviour provide further examples for the very partial success of state and church regulation. Among the many setbacks suffered by Johann Jacob Hürsch, minister of Neuenegg, who fought a constant if apparently futile campaign to improve the moral standards of his flock, was a tirade of insults by the drunken son of the local innkeeper after a sermon against "those people who preferred to be in the house of gluttony rather than that of the Lord." ${ }^{92}$ With regard to a thermal spa near Lauperswil in the Emmental, the local bailiff lamented in 1640 about the "scandalous and godless life, with many unnecessary activities such as dancing, singing, yelling, whistling, fiddling, gaming and gatherings in the Moosbad, ... taking place day and night, especially on Saturday evenings, when the lights are turned off and men and women, boys and girls, old and young people freely mingle in the same bathtub, ... [behaviour] which the landlord, Peter Schnyder, never actually reports to me.”93 Such reluctance to inform authorities about the

${ }^{91}$ Schmidt, Dorf und Religion, 133; similar evidence in Tanner, Spulen, 304.

92 Neuenegg, Chorgerichts-Manual 1.1, 9 January 1659 (“die jenigen menschen, welche lieber im Fräß vnd Sauff hauß sind v. blieben wöllen, als ins Herren Hauß”); for an example from Catholic France see César de Bus, Instructions familières (Paris, 1669), i. 157-8 (“Les villes et les villages sont remplis de cette sorte de profanateurs du saint Dimanche: car en premier lieu, combien y a-t-il de Laboureurs, de Vignerons, d'Artisans, et d'autres semblables gens, qui vont le Dimanche manger ou boire dans un cabaret tout ce qu’ils ont gagné durant la semaine à la sueur de leur visage?”).

${ }^{93}$ Cited in Adrian Lüthi, Die Mineralbäder des Kantons Bern. Wesen, Entwicklung und touristische Bedeutung (Diss. Rer. Pol. Bern: Burgdorf, 1957), 53 (the bailiff talks of “ehrgerlichen undt Gottloßen Läbens und unnützen Wäsens mit Tantzen, Singen, schreyen, pfyffen, Gygen, Spihlen und zu(o)sammen Lauffen by dem Mooßbad ... by tag undt nacht, sonderlich an Sambstagen zu(o) Nacht, mit nechtlicher ußlöschung der Liechteren undt undermischung Mannen und weiberen, Knaben und Meittlinen, alt und jungen, jnn einem Kasten ... solches aber weder durch Peter Schnyder, des Wirt daselbsten ... mir bim minsten geclagt”). Similar problems of enforcement are evident in France: Beck, Dimanche, 80. 
names and behaviour of patrons was common among early modern innkeepers, who faced an uncomfortable balancing act between commercial interests and the enforcement of moral imperatives. ${ }^{94}$ As public officials or even members of city and village councils, many were able to influence the enforcement of government policy in their favour. ${ }^{95}$ The jolly atmosphere in the spa, incidentally, throws yet more light on the presence of women in hostelries, whether they were officially supposed to be there or not. ${ }^{96}$

A closer examination of the social importance of inns and taverns, to conclude this brief survey, reinforces the recent scholarly emphasis on the limits of state control in the early modern period. ${ }^{97}$ Considering the constitutional framework, this should not be too surprising. Quite apart from the notorious shortcomings of the administrative system at the time, surviving communal and feudal prerogatives were still forces to be reckoned with. As illustrated above, the Bernese council simply did not have the legal powers to impose its policies in some of its urban and rural areas. Another important factor was the ambiguity of the authorities' own attitude. While worrying about all kinds of dangers associated with inns or taverns, early modern rulers could not ignore the practical, fiscal and social benefits of the hospitality network. ${ }^{98}$ The impact of central legislation thus depended on the specific situation (affecting the intensity of enforcement), region (determining the balance of power) and subject matter (commanding greater or lesser acceptance). Yet whatever the context, neither territorial states nor confessional churches could simply ride roughshod

94 Jütte, Poverty and Deviance, 66; Dülmen, Entstehung, 208.

${ }^{95}$ According to a provisional analysis of the information contained in the database, some 14 per cent of Bernese landlords held a public office.

${ }^{96}$ A similar conclusion in Soubeyroux, Pauperisme, i. 196-7.

${ }^{97}$ Nicholas Henshall, The Myth of Absolutism. Change and Continuity in Early Modern European Monarchy (2nd edn., London, 1993); Michael J. Braddick, “State formation and social change in early modern England. A problem stated and approaches suggested,” Social History 16 (1991), 1-17; Ronald Asch and Heinz Duchhardt, Der Absolutismus - ein Mythos? (Cologne, 1996).

98 “The transactions and social networking for which the tavern provided a public meeting place, the public income provided by taxes on the sale of alcoholic drinks, and the symbolic uses of alcohol by both popular and elite society were absolutely crucial to the survival of the community”: Tlusty, “The Devil’s Altar,” 40. 
over local concerns, ${ }^{99}$ even in the flagship protestant Republic of Bern. Landlords and landladies, dependent as they were on commercial success, needed to respond to the demands of their patrons. Reduced provision, fewer entertainments and ever closer supervision were not among them. With regard to numbers as well as legitimate activities, local preferences prevailed over central regulation. As flourishing social centres, inns and taverns answered to more than one master.

${ }^{99}$ Mark Forster, The Counter-Reformation in the Villages. Religion and Reform in the Bishopric of Speyer 1560-1720 (Ithaca, 1992); Beat Kümin, “The fear of intrusion. Communal resilience in early modern England,” Fear in Early Modern Society, ed. Penny Roberts and William Naphy (Manchester, 1997), 118-136; see also the contributions in Gemeinde und Staat im alten Europa, ed. Peter Blickle (Munich, 1998). 
